\title{
ANALISIS FAKTOR-FAKTOR YANG MEMPENGARUHITINGKAT KEPUASAN KONSUMENPADA PT. PERUSAHAAN LISTRIK NEGARA (PERSERO) WILAYAH II SUMUT
}

\author{
Junita Lubis \\ Dosen Tetap Sekolah Tinggi Ilmu Ekonomi (STIE) Labuhanbatu
}

\begin{abstract}
ABSTRAK
Pelayanan pegawai merupakan strategi perusahaan untuk merebut pangsa pasar dalam menghadapi persaingan, hal ini dikarenakan dengan memberikan pelayanan yang baik serta berkualitas kepada pelanggan sehingga pelanggan akan merasa dihargai dan mendapat kepuasan, selain itu pelanggan/konsumen merasa senang untuk menjadi pelanggan dan demikian sebaliknya.Masalah-masalah yang ditemukan pada PT. PLN (Persero) Wilayah II Sumatera Utara antara lain adalah kualitas pelayan pegawai yang diberikan telah memenuhi harapan pelanggan/konsumen sehingga pelanggan/konsumen menjadi puas atas pelayanan pegawai yang diberikan dan adanya sikap pelayanan pegawai yang kurang memenuhi harapan pelanggan/konsumen.Hasil penelitian menunjukkan bahwa pelayanan pegawai signifikan terhadap tingkat kepuasan pelanggan pada PT. PLN (Persero) Wilayah Sumatera Utara. Nilai koefisien determinasi $R$-square sebesar 0,936. Ini berarti bahwa secara uтum pelayanan pegawai terhadap tingkat kepuasan konsumen dalam skala mendekati constant return to scale.
\end{abstract}

Kata Kunci : Tingkat Kepuasan, Konsumen, Pelayanan, Kualitas Pelayanan

\section{PENDAHULUAN}

Setiap perusahaan terutama perusahaan berusaha untuk mencapai laba maksimal yang meningkat dan tujuan tersebut dapat tercapai dengan cara antara lain berorientasi kepada kepuasan konsumen/pelanggan, dan peningkatan pelayan pegawai. Perusahaan yang berorientasi pada kepuasan konsumen/pelanggan lebih menitik beratkan kepada pemenuhan dan keinginan pelanggan/konsumen.Namun dalam pencapaian tujuan tersebut (laba maksimal) perusahaan sering mengabaikan hak-hak konsumen/pelanggan yang sudah memberikan kewajibannya terhadap apa yang dihasilkan perusahaaan. Dalam hal ini, tidak jarang konsumen atau pelanggan mengeluh akibat lambatnya pelayanan pegawai yang dilakukan perusahaan.

Pelayanan pegawai dan kepuasan konsumen/pelanggan berkaitan erat, pelayanan pegawai yang baik memberikan suatu dorongan kepada konsumen/pelanggan untuk menjalin ikatan yang kuat dengan perusahaan. Dalam jangka panjang ikatan seperti ini memungkinkan perusahaan untuk memahami dengan seksama harapan konsumen/pelanggannya sertakebutuhan. Dengan demikian perusahaan dapat meningkatkan kepuasan pelanggan dimana perusahaan memaksimumkanpengalaman pelanggan yang menyenangkan dan 
meminimumkan atau meniadakan pengalaman pelanggan yang kurang menyenangkan. Pada gilirannya kepuasan pelanggan/konsumen dapat menciptakan kesetiaan atau loyalitas pelanggan/konsumen kepada perusahaan yang memberikan kualitas yang memuaskan.

PT. Perusahaan Listrik Negara (Persero) Wilayah II Sumatera Utara merupakan salah satu perusahaan dimana pelayanan pegawai sangat diperlukan untuk memberi kepuasan maksimal kepada para pelanggan/konsumennya. Ada beberapa syarat yang diperlukan dalam pelayanan pegawai diantara service advisor yang terlatih, suasana pelayanan pegawai yang modern dan maju, waktu pelayanan pegawai yang singkat, dan harga yang pantas (reasonable price).

Dengan dasar pemikiran yang sedemikian maka penulis berkeinginan untuk mengadakan penelitian terhadap kepuasan konsumen/pelanggan.

\section{Perumusan Masalah}

Berdasarkan latar belakang dan batasan masalah maka permasalahan dapat dirumuskan yaitu " Faktor pelayanan pegawai mempengaruhi kepuasan pelanggan pada PT. PLN (Persero) Wilayah Sumut? “

\section{Tujuan dan Manfaat Penelitian}

Adapun tujuan dari penelitian ini adalah :

1. Melihat sejauh mana pelayanan pegawai yang diberikan PT. PLN (Persero) Wilayah Sumut kepada konsumen/pelanggan.

2. Mengetahui pengaruh pelayanan pegawai terhadap kepuasan pelanggan/konsumen PT. PLN (Persero) Wilayah Sumut.

Sedangkan manfaat dari penelitian ini adalah :

1. Bagi penulis, dapat menambah wawasan berfikir penulis dalam bidang pemasaran terutama dalam hal pelayanan pegawai dan kepuasan pelanggan/konsumen.

2. Memberikan masukan bagi pihak manajemen PT. PLN (Persero) Wilayah Sumut dalam hal pelayanan pegawai terhadap kepuasan pelanggan/konsumen.

3. Bagi pihak lain, sebagai bahan perbandingan bagi pihak lain yang akan meneliti masalah yang sama dimasa mendatang.

\section{TINJAUAN TEORITIS}

\section{Pengertian Pelayanan}

Pada tiap-tiap perusahaan baik perusahaan industri maupun perusahaan jasa, pelayanan merupakan strategi perusahaan untuk merebut pangsa pasar dlam menghadapi persaingan. Hal ini dikarenakan dengan memberikan pelayanan yang baik serta berkualitas kepada pelanggan, maka pelanggan akan merasa mendapat kepuasan dan dihargai sehingga tetap merasa senangf untuk menjadi pelanggan perusahaan, demikian juga sebaliknya.

Pada hakekatnya pelayanan merupakan kegiatan yang tidak dapat didefenisikan secara tersendiri dan bersifat intangible (tidak teraba), yang merupakan pemenuhan kebutuhan dan tidak harus terikat pada penjualan produk atau pelayanan lainnya. Pelayanan dapat dikatakan sebagai aktivitas manfaat dan kepuasan yang ditawarkan untuk dijual. Hal ini dikarenakan pembelian suatu pelayanan seringkali juga melibatkan barang-barang yang 
melengkapi misalnya makanan direstoran, tamu yang menginap dihotel, telepon dalam jasa komunikasi, buku yang dijual ditoko buku, pemakaian listrik oleh pelanggan listrik dan sebagainya.

Menurut Swastha, (1995:318) mendifinisikan pelayanan sebagai berikut : “ barang yang tidak kentara (intangible product) yang dibeli dan dijual dipasar melalui suatu transaksi pertukaran yang saling memuaskan".

Dari definisi diatas dapat dilihat peranan pelayanan sangat diperlukan yang dititik beratkan pada para pelanggan yang datang keperusahaan dengan harapan untuk mendapatkan kepuasan tertentu. Sehingga diambil kesimpulan bahwa pelayanan yang efektif adalah pelayanan yang dapat memberikan kepuasan kepada pelanggannya.

Dengan demikian dapat diketahui bahwa pelayanan adalah setiap tindakanatau perbuatan menghasilkan satu tingkat kepuasan yang dapat ditawarkan untuk dijual, bersifat intngible, inseparability, variability dan perishability.

\section{Kualitas Pelayanan}

Kualitas adalah sebuah kata bagi penyedia jasa merupakan sesuatu yang harus dikerjakan dengan baik. Aplikasi kualitas sebagai sifat dari penampilan produk atau kinerja merupakan bagian utama strategis perusahaan dalam rangka meraih keunggulan yang berkesinambungan, baik sebagai pemimpin pasar atau sebagai strategi untuk terus tumbuh dan berkembang.Keunggulan suatu produk jasa adalah tergantung dari keunikan serta kualitas yang diperlihatkan oleh jasa tersebut, apakah sudah sesuai dengan harapan dan keinginan pelanggan.Dengan memahami, kemudian menggabungkan pendapat para ahli dapat diketahui bahwa kualitas pelayanan adalah suatu tingkat keunggulan dan merupakan output yang tidak berbentuk dan bermanfat bagi pelanggan dan tingkat tinggi rendahnya ditentukan oleh harapan pelanggan tersebut.

Pelayanan yang terbaik pada pelanggan dan tingkat kualitas dapat dicapai secara konsisten dengan memperbaiki pelayanan dan memberikan perhatian khusus pada standar kinerja pelayanan baik standar pelayanan internal maupun standar pelayanan eksternal.

\section{Konsep Pelayanan}

Kualitas memiliki hubungan yang erat dengan kepuasan pelanggan. Kualitas menekankan kepada aspek kepuasan pelanggan dan pendapatan. Kualitas memberikan suatu dorongan kepada pelanggan untuk menjalin ikatan hubungan yang kuat dengan perusahaan. Dalam jangka panjang ikatan seperti ini memungkinkan perusahaan untuk memahami dengan seksama harapan pelanggan serta kebutuhan mereka.

Pelayanan yang diberikan hendaknya pelayanan yang dapat memberikan rasa puas bagi sipenerima layanan tersebut dan pelayanan yang diberikan kepada pelanggan dituntut untuk selalu disempurnakan dan ditingkatkan baik mutu maupun kualitasnya pada masa yang akan datang.

\section{Kepuasan Pelanggan}

Pelanggan adalah kata kunci bagi kesuksesan perusahaan. Peran yang demikian penting telah memaksa setiap perusahaan berupaya untuk menyusun kiat atau strategi untuk menarik mereka, sehingga mereka menjadi pembeli produknya. Menurut Supranto, 


\section{Jurnal Ecobisma Vol 1 No. 12014}

(2007:233):'kepuasan adalah tingkat perasaan seseorang setelah membandingkan kinerja atau hasil yang dirasakan dengan harapannya".

Tingkat kepuasan konsumen merupakan fungsi dari perbedaan antara kinerja yang dirasakan dengan harapan. Apabila kinerja dibawah harapan, maka pelanggan akan kecewa. Pelanggan yang puas akan setia lebih lama, kurang sensitif terhadap harga dan memberikan komentar yang baik tentang perusahaan.

Menurut Wibowo (2008:29) pengertian customer mencakup tiga hal, yang menentukan baik buruknya pelayanan yang diberikan perusahaan. ketika pengertian tersebut adalah : (1) External customer yaitu mereka yang mempunyai pengalaman terhadap pelayanan yang diberikan oleh perusahaan, (2) Competitor customer yakni customer yang ingin direbut perusahaan, dari perusahaan lainyang sejenis, dan (3) Internal customer yaitu mereka yang menggantungkan pada pelayanan internal untuk menciptakan suatu pelayanan.

Dari pernyataan diatas terlihat bahwa pada dasarnya makna pelanggan terdiri dari 3 (tiga) hal yang menyangkut makna external customer, atau pelanggan yang telah memahami pelayanan perusahaan yang selanjutnya akan menentukan sikap kesetiaan pelanggan dan kelanjutan manfaat fasilitas pelayanan, apakah berlanjut atau tidak. Competitor customer atau pelanggan yang ingin diambil alih oleh perusahaan sejenis lainnya (pesaing), hal ini dapat mengancam perusahaan bila tidak diperhatikan sepenuhnya, atau perusahaan tidak memiliki kualitas pelayanan yang baik.

\section{Mengukur Kepuasan Pelanggan}

Sistem pengaduan ialah sistem yang memberikan kesempatan kepada pelanggan untuk memberikan saran, setiap saran dan keluhan yang masuk harus menjadi perhatian bagi perusahaan, sebab saran dan keluhan itu pada umumnya dilandasi oleh pengalaman mereka dan hal ini sebagai bentuk kecintaan mereka terhadap produk maupun terhadap perusahaan. Survey pelanggan adalah merupakan cara yang umum digunakan dalam mengukur kepuasan pelanggan misalnya, melalui surat pos, telepon, dan wawancara secara langsung. Panel perusahaan adalah perusahaan mengundang pelanggan yang setia terhadap produknya dan mengundang pelanggan yang telah berhenti memberi atau telah pindah menjadi pelanggan perusahaan lain. dari pelanggan serta akan diperoleh informasi tingkat kepuasan yang mereka rasakan dan pelanggan yang telah berhenti membeli, perusahaan akan memperoleh informasi mengapa hal itu dapat terjadi. apabila pelanggan yang berhenti ini meningkat hal ini menunjukkkan kegagalan perusahaan dalam memuaskan pelanggan.

\section{Hipotesis Penelitian}

Hipotesis merupakan jawaban yang sifatnya sementara, jawaban itu akan diterima apabila mengandung kebenaran dan akan ditolak apabila mengandung kesalahan. Dalam hal ini yang dapat membenarkannya adalah fakta-fakta yang ada dan terjadi (Sugiyono,2007:306). Adapun hipotesis dalam penelitian ini adalah "Tingkat Pelayanan pegawai yang diterapkan pada PT. PLN (Persero) Wilayah Sumut mempunyai pengaruh yang signifikan dalam meningkatkan kepuasan pelanggan".

\section{METODE PENELITIAN}


Data yang digunakan dalam penelitian ini adalah data primer dan sekunder, dari data yang dikumpulkan setelah diadakan penelitian dan pengumpula data melalui kuisioner berupa angket, diperoleh data tentang pengaruh maupun hubungan pelayanan pegawai dalam meningkatkan kepuasan pelanggan/konsumen pada PT. PLN (Persero) Wilayah Sumatera Utara, maka data tersebut disajikan dalam bentuk analisis data dengan populasi adalah karyawan di perusahaan tersebut sekaligus sebagai sampel dalam penelitian ini.

Adapun angket yang disebarkan tersebut adalah sebanyak 60 kuisioner kepada pelanggan/konsumen dan pegawai yang dijadikan sampel. Isi angket tersebut berupa pertanyaan sebanyak 30 pertanyaan dengan rincian yaitu 15 pertanyaan untuk variable pelayanan pegawai, dan 15 pertanyaan untuk variabel tingkat kepuasann pelanggan/konsumen dan untuk setiap pertanyaan 5 alternatif jawaban.

\section{Teknik Pengumpulan Data}

Data dalam penelitian ini dilakukan dengan menyusun teknik pengumpulan data :

a. Wawancara (interview)

Wawancara adalah teknik pengumpulan data dengan cara bertanya langsung kepada pihak yang berwenang memberikan data dan informasi yang berkaitan dengan tingkat pelayanan pegawai dan kepuasan pelanggan.

b. Pengamatan (Observasi)

Pengamatan dilakukan langsung ke objek penelitian dalam hal ini kegiatan yang dilakukan karyawan pada PT. PLN (Persero) Wilayah Sumut.

c. Angket (Quisioner)

Angket adalah pengumpulan data dan informasi yang diperoleh dengan cara menyebarkan angket (kuisioner) yang berisi pertanyaan yang berhubungan dengan permasalahan, dimana data tersebut digunakan sebagai acuan dan pertimbangan terhadap apa yang ada dilapangan untuk keperluan analisis data.

\section{Metode Analisis Data}

Metode dasar yang digunakan dalam penelitian ini ada 2 metode yaitu, metode analisis deskriptif dan metode analisis statistik. Metode analisis deskriptif dalam penelitian ini adalah merupakan uraian penjelasan antara pengaruh tingkat pelayanan pegawai terhadap kepuasan pelanggan/konsumen. Sedangkan metode analisis statistik yang digunakan adalah metode analisis regresi linier sederhana yang terdiri dari 1 (satu) variabel bebas terhadap 1 (satu) variabel terikat.Data yang digunakan pada penelitian ini adalah data hasil kuisioner yang telah diisi responden dan dikembalikan untuk kemudian dikumpulkan dan diklasifikasi lalu dimasukkan dalam tabel pengolahan data untuk selanjutnya diolah untuk mengetahui bobot nilai dari pertanyaan yang diajukan. Data tingkat pelayanan pegawai yang diasumsikan untuk penelitian ini adalah keseluruhan aspek pelayanan pegawai yang berlaku di PT. PLN (Persero) Wilayah II Sumatera Utara.

\section{Metode Analisis Regresi Linier Berganda}

Dalam penelitian ini digunakan analisis regresi berganda dalam bentuk logaritma (Tarmizi dan Sumodiningrat, 1989; Suryo Wardani, et al., 1995). Selain itu statistik deskripsi digunakan untuk menggambarkan keadaan umum daerah penelitian (Mason, et al., 1999). 
Dimaksudkan untuk menganalisis apakah terdapat hubungan antara pelayanan pegawai dengan kepuasan pelanggan. Secara umum dapat digambarkan sebagai berikut.

$$
\mathbf{Y}=\mathbf{b}_{\mathbf{0}}+\mathbf{b} \mathbf{1} \mathbf{X}+\mathbf{e}
$$

dimana:

$\mathrm{X}=$ Pelayanan Pelanggan

$\mathrm{Y} \quad=$ Kepuasan Pelanggan

b0 = Intercep

b1 = koefisien regresi

Pengujian model regresi sederhana ini digunakan untuk mengetahui pengaruh positif atau negatif dari masing-masing variabel bebas $(\mathrm{X})$ terhadap variabel terikat $(\mathrm{Y})$. Namun sebelum data tersebut dianalisis, model regresi sederhana diatas harus memenuhi syarat asumsi klasik yang meliputi uji Normalitas Residual, digunakan untuk menguji apakah dalam sebuah model regresi, variabel bebas, variabel terikat atau keduanya mempunyai distribusi normal atau tidak.

\section{Koefisien Determinasi}

Koefisien determinasi $\left(\mathrm{R}^{2}\right)$ digunakan untuk mengukur seberapa jauh kemampuan variabel bebas yang dimasukkan dalam model, dalam menjelaskan variabel-variabel terikat. Nilai koefisien determinasi adalah $\left(0<R^{2}<1\right)$. Selanjutnya penyelesaian analisis ini menggunakan program SPSS, sehingga untuk menilai hasil regresi dilakukan dengan melihat nilai masing-masing koefisien dari keluaran program SPSS tersebut.

\section{Uji t (Uji secara parsial)}

Uji statistik t yang pada dasarnya adalah menunjukkan seberapa jauh pengaruh satu variabel penjelas secara individual dalam mempengaruhi variabel terikat. Apakah suatu variabel indipenden merupakan penjelas yang signifikan atau tidak signifikan terhadap variabel dependen. Dalam statistik dapat dicari melalui rumus (Gujarati, 2003).

$$
\mathrm{t}=\text {---------- }
$$

dimana $\mathrm{t}=$ nilai yang dicari; $\beta \mathrm{i}=$ koefisien regresi . Bila $\mathrm{t}$ hitung $>\mathrm{t}$ tabel pada tingkat kepercayaan 5\% atau nilai probabilitas signifikansi lebih kecil dari 0,05 (taraf nyata 5\%) maka H0 ditolah dengan kata lain variabel bebas berpengaruh secara signifikan terhadap variabel terikat.

\section{HASIL DAN PEMBAHASAN}

Dari uji analisis regresi linier dalam penelitian ini konstanta $\left(b_{0}\right)=7.971$, menunjukkan bahwa adanya terjadi peningkatan berdasarkan tanda positif pada nilai konstanta yang berarti dengan pelayanan pegawai yang baik pada PT.PLN (Persero) Wilayah Sumut maka tingkat kepuasan konsumen meningkat sebesar 79,71\%.

Koefisien regresi $\mathrm{X}(\mathrm{b} 1)=0.881$ menunjukkan bahwa variabel tingkat pelayanan pegawai (X) pada PT.PLN (Persero) Wilayah Sumut memiliki pengaruh signifikan terhadap kepuasan pelanggan/konsumen (Y). Atau dengan kata lain, jika tingkat pelayanan pegawai ditingkatkan sebesar 1 kali maka kepuasan konsumen akan meningkat sebesar 8,81\%. 


\section{Jurnal Ecobisma Vol 1 No. 12014}

Sehingga dapat dikatakan bahwa semakin tinggi nilai tingkat pelayanan pegawai akan semakin tinggi pula tingkat kepuasan konsumen atau sebaliknya. Semakin turun nilai tingkat pelayanan pegawai akan menurunkan tingkat kepuasan. Oleh sebab itu variabel tingkat pelayanan pegawai dapat dikatakan sudah memiliki hubungan searah terhadap kepuasan pelanggan/konsumen pada PT. PLN (Persero) Wilayah Sumut.

Dari hasil pengujian koefisien korelasi Nilai koefisien $\left(\mathrm{R}^{2}\right)$ adalah 0.936 berada diantara $0 \leq \mathrm{R}^{2} \leq 1$, artinya bahwa peningkatan kepuasan pelanggan/konsumen pada PT. PLN (Persero) Wilayah Sumut dipengaruhi oleh variabel tingkat pelayanan pegawai sebesar 93,6\% sedangkan sisanya sebesar $6,4 \%$ dipengaruhi oleh faktor lain yang tidah dimasukkan dalam penelitian ini.

Hasil uji t adalah variabel bebas (tingkat pelayanan pegawai) secara parsial memiliki pengaruh secara signifikan terhadap variabel terikat (kepuasan pelanggan/konsumen) dan pengaruh yang ditimbulkan dari variabel bebas adalah pengaruh positif dimana peningkatan pelayanan pegawai akan meningkatkan jumlah penjualan.

\section{Kesimpulan}

PT. PLN (Persero) Wilayah II Sumatera Utara merupakan perusahaan BUMN yang bergerak di bidang pengolahan kelistrikan di wilayah Sumatera Utara yang berkantor pusat di J1 Listrik No. 12 Medan. Dari uji koefisien korelasi bahwa peningkatan kepuasan pelanggan/konsumen pada PT. PLN (Persero) Wilayah Sumut dipengaruhi oleh variabel tingkat pelayanan pegawai sebesar $93,6 \%$ sedangkan sisanya sebesar $6,4 \%$ dipengaruhi oleh faktor lain.

\section{DAFTAR PUSTAKA}

Arikunto,Suharsimi.2003.Prosedur Penelitian,Jakarta:Bumi Aksara

Basu Swatha,DH.1995.Azas-azaz Pemasaran. Yogyakarta: Liberty

Budi W. Soejipto.2006. Service Quality: Alternatif Pendekatan dan Berbagai Persoalan di Indonesia, Usahawan No. 01 Th.XXVI Januari.

Hermawan Kartajaya.2003. Marketing Plus 3. Jakarta : Pustaka Sinar Harapan

Lupiyoadi,Rambat.2000. Pemasaran Jasa. Jakarta: Salemba Empat

Sudjana.2000.Metode Statistika. Bandung: Tarsito

Sugiyono.2007. Metode Penelitian Bisnis. Bandung : Alfabeta

Tjiptono, Fandi.2006. Manajemen Jasa. Edisi II. Yogyakarta: Andi Offset 